\title{
Model Contextual Teaching Learning (CTL) untuk Meningkatkan Kemampuan Pemecahan Masalah Matematis Siswa SMP
}

\author{
Putri Zuliyanti ${ }^{1, *}$, Heni Pujiastuti ${ }^{2}$ \\ 1,2 Universitas Sultan Ageng Tirtayasa \\ *putrizuliyanti98@gmail.com \\ \begin{tabular}{|l|l|l|}
\hline Received : 29-3-2020 & Revised: 9-4-2020 & Accepted: $11-4-2020$ \\
\hline
\end{tabular}
}

\begin{abstract}
ABSTRAK
Pemecahan masalah merupakan landasan dalam pembelajaran matematika, tanpa kemampuan pemecahan masalah pada diri peserta didik maka kegunaan dan kekuatan ide-ide matematika, pengetauan, dan keterampilannya sangat terbatas. Dalam penelitian ini peneliti akan meneliti terkait pengaruh model Contextual Teaching Learning (CTL) terhadap peningkatan kemampuan pemecahan masalah matematis siswa SMP pada materi Sistem Persamaan Linear Dua Variabel (SPLDV). Penelitian ini dilakukan di SMPN 1 Kramatwatu Tahun Pelajaran 2019/2020. Metode penelitian yang digunakan yaitu metode Quasi Eksperimen dan lebih dikhususkan kepada eksperimen semu dengan desain kelompok Pretest - Posttest Control Grup Desaign. Populasi penelitian yaitu pesert didik di SMPN 1 Kramatwatu, sedangkan subjek penelitian ini adalah 54 peserta didik yang terdiri dari 27 peserta didik kelas eksperimen yang memperoleh pembelajaran dengan pendekatan Contextual Teaching and Learning (CTL) dan 27 peserta didik kelas kontrol yang memperoleh pembelajaran konvensional. Hasil penelitian ini menunjukkan bahwa nilai Asymp. Sig. (2-tailed) sebesar $0.000<0.05$. Hal ini berarti Ho di tolak dan Ha diterima. Sehingga dapat dikatakan bahwa rata-rata kemampuan pemecahan masalah matematis peserta didik kelas eksperimen yang diberikan pembelajaran dengan pendekatan CTL pada materi SPLDV lebih baik dibandingkan dengan rata-rata kemampuan pemecahan masalah matematis peserta didik pada kelas kontrol yang diberikan pembelajaran konvensional pada materi SPLDV.
\end{abstract}

Kata Kunci : Matematika, Pemecahan Masalah, Contextual Teaching and Learning (CTL).

\section{ABSTRACT}

Problem solving is the foundation in learning mathematics, without the ability to solve problems in students themselves, the usefulness and strength of mathematical ideas, knowledge, and skills are very limited. In this study, researchers will examine the effect of the Contextual Teaching Learning (CTL) model on improving the ability to solve mathematical problem solving for junior high school students on the Material Variable Linear Equation System (SPLDV). This research was conducted at SMPN 1 Kramatwatu, with the 2019/2020 Academic Year. The research method used is the Quasi Experiment method and is more specialized in pseudo experiments with the design group Pretest Posttest Control Desaign Group. The study population was students at SMPN 1 Kramatwatu, while the subjects of this study were 54 students consisting of 27 experimental class students who obtained learning using the Contextual Teaching and Learning (CTL) approach and 27 control class students who obtained conventional learning. The results of this study indicate that the Asymp value. Sig. (2tailed) of 0,000 <0.05. This means that Ho is rejected and Ha is accepted. So it can be said that the average mathematical problem solving ability of experimental class students who are given learning by the CTL approach on SPLDV material is better than the average mathematical problem solving ability of students in the control class given conventional learning on SPLDV material.

Keywords: Mathematics, Problem solving, Contextual Teaching and Learning (CTL). 


\section{PENDAHULUAN}

Pembelajaran matematika merupakan salah satu mata pelajaran di sekolah yang memiliki peranan penting dalam kehidupan sehari-hari bahkan dalam kehidupan ilmu pengetahuan dan teknologi, oleh karena itu pembelajaran matematika merupakan ilmu pendidikan yang turut andil dalam memajukan pendidikan di Indonesia.

Pembelajaran matematika sangatlah penting dalam meningkatkan cara berpikir peserta didik terutama cara berpikir peserta didik dalam menyelesaikan permasalahan, dan dapat melatih siswa agar mampu berfikir kritis secara logis, rasional, cermat, jujur, efektif, dan efisien. Sesusai dengan Peraturan Menteri Pendidikan nasional No. 22 tahun 2016 tentang standar proses, yang menyatakan bahwa proses pembelajaran pada setiap satuan dasar dan menengah harus interaktif, inspiratif, menyenangkan, menantang, dan memotivasi peserta didik untuk berpartisipasi aktif, serta memberikan ruang yang cukup bagi prakarsa, kreativitas, dan kemandirian sesuai dengan bakat, minat, dan perkembangan fisik serta psikologis peserta didik.

Dengan memperhatikan Peraturan Menteri Pendidikan nasional No. 22 tahun 2016 tentang standar proses dan pentingnya pembelajaran matematika, maka kemampuan pemecahan masalah matematis merupakan faktor yang penting dalam mengimplementasikannya. Pemecahan masalah merupakan landasan dalam pembelajaran matematika, tanpa kemampuan pemecahan masalah pada diri peserta didik maka kegunaan dan kekuatan ide-ide matematika, pengetauan, dan keterampilannya sangat terbatas (FerriniMundy, 2000; Septian, 2017; Suwarman, 2017). Berarti pemecahan masalah adalah prinsip dasar peserta didik dalam mempelajari matematika di sekolah merupakan salah satu bentuk kemampuan matematis yang paling dasar dan utama. Di dalam memecahkan masalah tentu saja harus ada masalah-masalah yang harus dipecahkan dengan benar, selain itu peserta didik juga mampu merumuskan dan menyelesaikan cara penyelesaiannya (Muhammad, Septian, \& Sofa, 2018).

Dengan demikian peserta didik diharapkan dapat memecahkan permasalahan matematis. Polya mengartikan bahwa pemecahan masalah merupakan salah satu usaha untuk mencari solusi dari suatu kesulitan untuk mencapai suatu tujuan yang tidak mudah untuk dicapai atau diselesaikan (Shadiq, 2004). Terdapat beberapa tahap pemecahan masalah matematis menurut Polya yaitu: Understanding the problem (memahami problem), Devising a plan (merancang rencana), Carrying out the plan (melakukan rencana), Looking back (melihat kembali) (Shadiq, 2004). 
Melalui pemecahan masalah matematis peserta didik tidak hanya dapat menyelesaikan pemecahan masalah yang ada, tetapi peserta didik dapat meningkatkan daya analisis dan dapat menolong peserta didik dalam menerapkan daya analisisnya diberbagai situasi baik dalam bidang studi matematika maupun dikehidupan sehari-hari (Bell, 1978; Ruseffendi, 2006), serta dapat berdampak pada ingatan peserta didik tentang materi pelajaran yang diajar.

Dilihat dari hasil survey PISA 2009, peserta didik yang mampu menerapkan prosedur dan strategi pemecah masalah hanya $15,5 \%$, sedangkan dari hasil penelitian TIMSS tahun 2011 menunjukkan rata-rata skor hasil belajar peserta didik dalam pembelajaran matematika di Indonesia sebesar 386 dibawah standar nilai TIMSS yaitu 500 (Organisation for Economic Co-operation and Development-OECD, 2010). Artinya peserta didik di Indonesia, dalam menyelesaikan pemecahan masalah matematis masih sangat rendah (Inayah, Septian, \& Suwarman, 2020).

Salah satu penyebab rendahnya kemampuan pemecahan masalah matematis peserta didik yaitu karena dipengaruhi oleh pendekatan model pembelajaran yang digunakan guru. Selain itu salah satu penyebabnya yaitu guru masih menerapkan metode ceramah atau konvensional yang berfokus pada guru sehingga guru lebih aktif di kelas sedangkan peserta didik hanya mendengar dan menjadi pasif (Maskur et al., 2020; Murnaka, Anggraini, \& Surgandini, 2018; Septian \& Komala, 2019). Proses pembelajaran konvensional, peserta didik hanya menerima konsep langsung dari guru dan terbiasa mendapatkan hasil penyelesaian masalah dari guru, sehingga siswa tidak terlatih untuk menggunakan nalarnya (Dewi, 2018). Peserta didik cenderung menggunkan pengetahuannya dalam mengerjakan sehingga peserta didik hanya menggunakan prosedur dan algortima, dibanding pengalaman sehari-hari.

Dalam melaksanakan pembelajaran, seorang guru hendaknya menerapkan model pembelajaran yang dapat membantu siswa dalam mengembangkan ide dan mengkontruksi pengetahuan dengan kehidupan sehari-hari baik dilakukan secara langsung maupun berbimbing (Fatimah et al., 2019), sehingga pembelajaran di kelas dapat berjalan dengan efektif dan efisien serta tujuan pembelajaran tercapai dengan maksimal. Salah satu alternatif yang dapat dilakukan oleh guru untuk meningkatkan pemecahan masalah matematis peserta didik yaitu dengan menerapkan model pembelajaran Contextual Teaching and Learning (CTL). Model pembelajaran kontekstual atau Contextual Teaching and Learning (CTL) memiliki filosofi kontruktivisme yaitu belajar tidak hanya menghafal saja, melainkan 
mengkontruksi pengetahuan yang ada dalam peserta didik dengan kehidupan sehari-hari (Jusniani, 2018).

Pembelajaran kontekstual atau Contextual Teaching and Learning (CTL) adalah sebuah sistem yang merangsang otak untuk menyusun pola-pola yang mewujudkan makna dengan menghubungkan pembelajaran dengan kejadian yang ada pada kehidupan sehari-hari (Rusman, 2011). Pendekatan pembelajaran dengan model Contextual Teaching and Learning (CTL) merupakan pembelajaran yang diawali dengan mengambil cerita atau menceritakan kejadian yang ada pada dunia nyata dalam kehidupan sehari-hari yang dialami peserta didik kemudian diangkat ke dalam konsep matematika yang akan dibahas (Tati, Zulkardi, \& Hartono, 2013).

Dengan menerapkan pembelajaran model kontekstual atau Contextual Teaching and Learning $(C T L)$ serta melibatkan tujuh komponen utama pembelajaran kontekstual, yakni: konstruktivisme (contructivism), bertanya (questioning), inquiri (inquiry), masyarakat belajar (learning community), pemodelan (modelling), dan penilaian autentik (authentic assessment) dapat membantu guru dalam pembelajaran terutama pada pembelajaran matematika yang dapat mengkaitkan antara materi yang didapat dari guru dengan keadaan dunia nyata dan dapat mendorong peserta didik dalam memecahkan masalahnya dengan mengkaitkan pengetahuan yang dimilikinya serta menerapkan pada kehidupan sehari-hari (Trianto, 2010).

Berdasarkan permasalahan diatas maka salat satu materi didalam pembelajaran matematika yang dapat menghubungkan pemecahan masalah dengan kehidupan sehari-hari adalah materi Sistem Persamaan Dua Variabel. Hal yang biasanya dijumpai dalam kehidupan sehari-hari yang berkaitan dengan materi Sistem Persamaan Linear Dua Variabel (SPLDV) yaitu menentukan jumlah suatu harga, satu harga, jumlah harga, dan lain-lain. Dengan menggunakan model pembelajaran Contextual Teaching and Learning (CTL) yang mengkaitkan materi pembelajaran dengan kehidupan sehari-hari merupakan solusi efektif dalam meningkatkan kemampuan macalah materi SPLDV (Fitriani, 2017).

Sehingga berdasarkan pemaparan di atas maka tujuan pada penelitian ini yaitu meningkatkan kemampuan pemecahan masalah matematis dengan menggunakan model pembelajaran Contextual Teaching an Learning (CTL) pada materi SPLDV di bangku Sekolah Menengah Pertama (SMP). 


\section{METODE PENELITIAN}

Jenis penelitian ini merupakan penelitian kuantitatif. Metode yang digunakan dalam penelitian yaitu metode Quasi Eksperimen dan lebih dikhususkan kepada eksperimen semu. Dengan membandingkan satu kelompok eksperimen yang diberikan perlakuan yaitu model Contextual Teaching Learning (CTL) dengan satu kelompok pembanding yang tidak menerima perlakuan yaitu dengan pembelajaran biasa atau konvensional. Desain yang digunakan dalam penelitian ini adalah desain "Pretest - Posttest Control Grup Desaign" (Sugiyono, 2013) dengan rancangan seperti pada Tabel 1.

Tabel 1. Desain Penelitian

\begin{tabular}{cccc}
\hline Kelas & Pretest & Perlakuan & Posttest \\
\hline Eksperimen & $\mathrm{X}_{1}$ & $\mathrm{O}_{2}$ & $\mathrm{X}_{2}$ \\
\hline Kontrol & $\mathrm{X}_{1}$ & $\mathrm{O}_{1}$ & $\mathrm{X}_{2}$ \\
\hline
\end{tabular}

\footnotetext{
Keterangan:

$\mathrm{X}_{1}=$ tes awal atau pretest

$\mathrm{X}_{2}=$ tes akhir atau posttest

$\mathrm{O}_{1}=$ Perlakuan terhadap kelompok eksperimen yaitu dengan menerapkan model pembelajaran Contextual Teaching and Learning (CTL)

$\mathrm{O}_{2}=$ Perlakuan terhadap kelompok kontrol yaitu dengan model konvensional
}

Penelitian yang dilakukan yaitu di SMPN 1 Kramatwatu. Kabupaten Serang. Populasi penelitian adalah seluruh peserta didik kelas VIII SMPN 1 Kramatwatu, sedangkan sampel yang diambil menggunakan teknik purposive sampling yaitu memilih peserta didik kelas VIII-A sebagai kelas eksperimen dan VIII-B sebagai kelas kontrol. Pengumpulan data dilakukan melalui pretest dan posttest pada dua kelas yaitu keas VIII-A dan VIII-B materi SPLDV (Sistem Persamaan Liner Dua Variabel). Analisis data menggunakan analisis deskriptif, uji normalitas dan uji homogenitas kemudian jika menghasilkan data normal dan homogen maka dilakukan uji parametrik yaitu uji t, sedangkan jika menghasilkan data yang tidak normal dan tidak homogen maka dilakukan dengan uji non parametrik yaitu Mann Whitney.

Dalam penelitian ini instrumen yang digunakan yaitu lembar tes uraian kemampuan pemecahan masalah matematis materi SPLDV yang diberikan sebelum pembelajaran (pretest) dan setelah pembelajaran (posttest).

\section{HASIL DAN PEMBAHASAN}

Penelitin ini dilaksanakan di SMPN 1 Kramatwatu Kecamatan Kramatwatu Kabupaten Serang. Sampel penelitian yang diambil yaitu kelas VIII D sebagai kelas 
eksperimen dan kelas VIII I sebagai kelas kontrol, dengan materi yang diajarkan pada penelitian ini yaitu SPLDV (Sistem Persamaan Linear Dua Variabel). Penelitian ini dilakukan sebanyak 1 kali pertemuan.

Berikut ini merupakan hasil penelitian statistik deskriptif terhadap peningkatan kemampuan pemecahan masalah matematis peserta didik untuk data pretest dan posttest pada kelas eksperimen dan kontrol yang disajikan sebagai berikut:

Tabel 2. Deskriptif Statistik

\begin{tabular}{lccccc}
\hline & N & Minimum & Maximum & Mean & $\begin{array}{c}\text { Std. } \\
\text { Deviation }\end{array}$ \\
\hline $\begin{array}{l}\text { Pre-Test } \\
\text { Eksperimen }\end{array}$ & 27 & 50.0 & 90.0 & 72.148 & 13.8771 \\
\hline $\begin{array}{l}\text { Post-Test } \\
\text { Eksperimen }\end{array}$ & 27 & 65.0 & 100.0 & 82.731 & 11.7774 \\
\hline $\begin{array}{l}\text { Pre-Test Kontrol } \\
\text { Post-Test Kontrol }\end{array}$ & 27 & 45.0 & 75.0 & 58.648 & 7.3207 \\
\hline Valid N (listwise) & 27 & 55.0 & 85.0 & 69.037 & 6.2264 \\
\hline
\end{tabular}

Berdasarkan Tabel 2, diperoleh hasil bahwa kemampuan pemecahan masalah matematis peserta didik yang memperoleh pembelajaran dengan pendekatan CTL (kelas eksperimen) pada materi SPLDV secara data keseluruhan menunjukkan rata-rata peningkatan kemampuan pemecahan masalah matematis lebih besar dibandingkan dengan peserta didik yang memperoleh pembelajaran konvensional (kelas kontrol) pada materi SPLDV.

Analisis penelitian ini digunakan untuk menguji hipotesis yaitu peningkatan kemampuan pemecahan masalah matematis peserta didik yang mendapatkan pembelajaran dengan pendekatan CTL lebih baik dibanding peserta didik yang mendapatkan pembelajaran kovensional. Sehingga dilakukan uji normalitas dan uji homogenitas varian dua kelas sebelum dilakukan uji perbedaan dua rata-rata, yaitu sebagai berikut:

Tabel 3. Hasil Uji Homogenitas dan Normalitas

\begin{tabular}{|c|c|c|c|c|c|c|c|}
\hline & \multirow[t]{2}{*}{ Kelas } & \multicolumn{3}{|c|}{ Kolmogorov-Smirnov ${ }^{\mathrm{a}}$} & \multicolumn{3}{|c|}{ Shapiro-Wilk } \\
\hline & & Statistic & df & Sig. & $\begin{array}{c}\text { Statisti } \\
\mathrm{c}\end{array}$ & df & Sig. \\
\hline \multirow{5}{*}{$\begin{array}{l}\text { Hasil } \\
\text { Belajar }\end{array}$} & Pre-Test & 0.247 & 27 & 0.000 & 0.789 & 27 & 0.000 \\
\hline & Eksperimen & & & & & & \\
\hline & $\begin{array}{l}\text { Post-Test } \\
\text { Eksperimen }\end{array}$ & 0.176 & 27 & 0.032 & 0.907 & 27 & 0.019 \\
\hline & Pre-Test Kontrol & 0.212 & 27 & 0.003 & 0.883 & 27 & 0.006 \\
\hline & Post-Test Kontrol & 0.217 & 27 & 0.002 & 0.891 & 27 & 0.008 \\
\hline
\end{tabular}

a. Lilliefors Significance Correction 
Berdasarkan hasil Tabel 3, diperoleh bahwa hasil bahwa nilai Sig. (Signifikansi) untuk beberapa data baik pada uji Kolmogorov-Smirnov maupun uji Shapiro-Wilk yaitu < 0,05 atau $5 \%$, dan hanya terdapat satu data yang menghasilkan $>0,05$ atau $5 \%$ yaitu data post-test eksperimen, sehingga tidak dapat dilakukan uji statistika parametrik maka harus dilakukan uji statistika non parametrik yaitu dengan uji Mann-Whitney.

Uji statistika non parametrik yang digunakan untuk menjawab tujuan penelitian ini yaitu dengan uji Mann-Whitney. Kriteria yang digunakan dalam uji ini yaitu jika didapat nilai Sig. (2-tailed) < 0.05, maka Ho ditolak. Hipotesis penelitian untuk uji Mann-Whitney adalah: 1) Ho : tidak terdapat perbedaan kemampuan pemecahan masalah matematis peserta didik antara kelas eksperimen dengan kelas kontrol; 2) Ha : terdapat perbedaan kemampuan pemecahan masalah matematis peserta didik antara kelas eksperimen dan kelas kontrol. Hasil uji perbedaan kemampuan pemecahan masalah matematis pada tabel berikut:

\begin{tabular}{lr}
\multicolumn{2}{c}{ Tabel 4. Hasil Uji Mann-Whitney } \\
\hline \multicolumn{2}{c}{ Posttest Peserta Didik } \\
\hline Mann-Whitney U & 140.500 \\
\hline Wilcoxon W & 518.500 \\
\hline Z & -3.894 \\
\hline Asymp. Sig. (2-tailed) & 0.000 \\
\hline a. Grouping Variable: Kelas
\end{tabular}

Dari Tabel 4, diperoleh bahwa nilai Asymp. Sig. (2-tailed) sebesar $0.000<0.05$. Hipotesis penelitian ini terdiri dari: 1) Ho : tidak terdapat perbedaan kemampuan pemecahan masalah matematis peserta didik antara kelas eksperimen dengan kelas kontrol; 2) Ha : terdapat perbedaan kemampuan pemecahan masalah matematis peserta didik antara kelas eksperimen dan kelas kontrol, dengan pengambilan keputusan yaitu jika probabilitas >0,05 maka Ho ditolak, sedangkan jika probabilitas < 0,05 maka Ha diterima,. Hal ini berarti Ho di tolak dan Ha diterima, karena nilai Asymp. Sig. (2-tailed) kurang dari 0,05. Sehingga dapat dikatakan bahwa terdapat perbedaan kemampuan pemecahan masalah matematis peserta didik antara kelas eksperimen dengan kelas kontrol pada materi SPLDV. Karena terdapat perbedaan yang signifikan antara kelas eksperimen dan kelas kontrol pada materi SPLDV, maka dapat dikatakan bahwa terdapat pengaruh penggunaan model Contextual Teaching Learning (CTL) terhadap pemecahan masalah matematis peserta didik pada materi SPLDV.

Penelitian ini dilakukan selama satu kali pertemuan. Pertemuan pertama pada waktu jam pertama yaitu pada kelas VIII D dan jam kedua yaitu pada kelas VIII I, terlebih dahulu peneliti memberikan soal pretest untuk mengetahui kemampuan awal peserta didik, 
kemudian peneliti memberikan pembelajaran. Pada kelas VIII D peneliti memberikan pembelajaran dengan model CTL yang akan di terapkan kepada peserta didik, selanjutnya, peneliti memberi arahan kepada peserta didik untuk melakukan kerja kelompok untuk memecahkan suatu permasalahan pada pelajaran matematika. Sedangkan, pada kelas VIII I peneliti memberikan pembelajaran dengan model konvensional.. Pada akhir pertemuan dikelas VIII D dan VIII I, peserta didik diberikan posttest berupa soal uraian, untuk mengetahui kemampuan pemecahan masalah matematis dengan menggunakan model pembelajaran CTL dan dengan menggunakan model konvensional.

Berdasarkan permasalahan yang diteliti, maka diperoleh data hasil kemampuan pemecahan masalah matematis peserta didik. Hasil kemampuan pemecahan masalah matematis pada kelas eksperimen (VIII D) didapat nilai untuk pretest terendah 0 dan nilai tertinggi 20, serta posttest terendah 65 dan tertinggi 100. Sedangkan, pada kelas kontrol (VIII I) didapat nilai untuk pretest terendah 0 dan tertinggi 15 , serta posttest terendah 5 dan tertinggi 35 .

Penelitian ini dilakukan untuk meningkatkan pemecahan masalah matematis dengan model CTL lebih baik dibanding dengan model pembelajaran konvensional pada peserta didik kelas VIII dengan materi SPLDV. Dari hasil data penelitian pemecahan masalah matematis didapat pembelajaran dengan model CTL lebih baik dan memiliki perbedan yang signifikan dengan pembelajaran model konvensional sehingga pengaruh model CTL berpengaruh pada peningkatan pemecahan masalah matematis. Hal ini dapat dilihat dari hasil nilai rata-rata pada kelas eksperimen lebih besar yaitu 82,731, sedangkan pada kelas kontrol mendapatkan hasil nilai rata-rata yaitu 69,037.

Hasil penelitian ini sejalan dengan penelitian Cochran et. al. (2007) yang menunjukkan bahwa pembelajaran dengan model Contextual Teaching Learning bagi peserta didik dapat memperdalam pemahaman dan meningkatkan pemecahan masalah (Sari, Sari, Ikhsan, \& Sari, 2014). Pada saat pembelajaran berlangsung, peserta didik dapat terlibat langsung dalam kegiatan belajar dan menuntut mereka untuk mengkonstruksi dan memahami materi yang dipelajari, serta dengan berdiskusi antar anggota kelompok mereka dapat berkomunikasi secara aktif sehingga memberikan penguatan pemahaman pengetahuan dan mudah untuk memecahkan suatu permasalahan matematis.

\section{KESIMPULAN}

Berdasarkan hasil penelitian yang dilakukan dapat disimpulkan bahwa peserta didik yang memperoleh pembelajaran dengan pendekatan CTL (kelas eksperimen) pada materi 
SPLDV secara data keseluruhan menunjukkan rata-rata peningkatan kemampuan pemecahan masalah matematis lebih besar dibandingkan dengan peserta didik yang memperoleh pembelajaran konvensional (kelas kontrol) pada materi SPLDV. Sehingga terdapat perbedaan peningkatan antara pembelajaran model CTL dan konvensional, serta dengan pembelajaran model CTL lebih berpengaruh terhadap peningkatan pemecahan masalah matematis peserta didik, dibandingkan dengan pembelajaran model konvensional.

\section{REFERENSI}

Bell, F. H. (1978). Teaching and learning mathematics in Secondary School. 1978.

Dewi, P. S. (2018). Efektivitas Pendekatan Open Ended Ditinjau dari Kemampuan Pemecahan Masalah Matematis. PRISMA. VII(1), 11-19.

Fatimah, R. N., Kariadinata, R., Susilawati, W., Jihad, A., Nur, I., Fauziah, ... Sugilar, H. (2019). Teknik Probing-Promting Scaffolding pada Pemecahan Masalah Matematis. Prisma, 8(2), 146-159.

Ferrini-Mundy, J. (2000). Principles and standards for school mathematics: A guide for mathematicians. Notices of the American Mathematical Society, 47(8).

Fitriani, N. L. (2017). Efektivitas Pembelajaran Contextual Teaching and Learning (Ctl) Terhadap Kemampuan Pemecahan Masalah Matematika Peserta Didik pada Materi Sistem Persamaan Linier Dua Variabel (Spldv) Kelas VII MTsN Brangsong Tahun Pelajaran 2016/2017. Universitas Islam Negeri Walisongo Semarang.

Inayah, S., Septian, A., \& Suwarman, R. F. (2020). Student Procedural Fluency in Numerical Method Subjects. Desimal: Jurnal Matematika, 3(1), 53-64. https://doi.org/10.24042/djm.v3i1.5316

Jusniani, N. (2018). Analisis Kesalahan Jawababn Siswa Pada Kemampuan Pemahaman Matematis Melalui Pembelajaran Kontekstual. Prisma, VII(1), 82-90.

Maskur, R., Sumarno, Rahmawati, Y., Pradana, K., Syazali, M., Septian, A., \& Palupi, E. K. (2020). The effectiveness of problem based learning and aptitude treatment interaction in improving mathematical creative thinking skills on curriculum 2013. European Journal of Educational Research, 9(1), 375-383. https://doi.org/10.12973/eujer.9.1.375

Muhammad, G. M., Septian, A., \& Sofa, M. I. (2018). Penggunaan Model Pembelajaran Creative Problem Solving untuk Meningkatkan Kemampuan Pemecahan Masalah Matematis Siswa. Mosharafa: Jurnal Pendidikan Matematika, 7(3), 315-326. https://doi.org/10.31980/mosharafa.v7i3.140

Murnaka, N., Anggraini, B., \& Surgandini, A. (2018). Efektifitas Pembelajaran Dengan Pendekatan Contextual Teaching And Learning (CTL) Untuk Meningkatkan Kemampuan Pemecahan Masalah Matematis. Jurnal Derivat: Jurnal Matematika Dan Pendidikan Matematika, 5(1), 30-36.

Organisation for Economic Co-operation and Development-OECD. (2010). PISA 2009 Results: Executive Summary. Executive Summary, 1-21.

Ruseffendi, E. . T. . (2006). Pengantar kepada Membantu Guru Mengembangkan Kompetensinya dalam Pengajaran Matematika untuk Meningkatkan CBSA. (2001), 8410092.

Rusman. (2011). Model-model Pembelajaran. 63-77.

Sari, N. T., Sari, N. T., Ikhsan, M., \& Sari, N. T. (2014). Implementasi Pendekatan Contextual Teaching and Learning (CTL) Bernuansa Pendidikan Karakter untuk Meningkatkan Kemampuan Pemecahan Masalah Matematis Siswa MTsN. 1(1), 46-60. https://doi.org/10.24815/dm.v1i1.1338 
Septian, A. (2017). Penerapan Geogebra untuk Meningkatkan Kemampuan Pemecahan Masalah Matematis Mahasiswa Program Studi Pendidikan Matematika Universitas Suryakancana. PRISMA, 6(2). https://doi.org/10.35194/jp.v6i2.212

Septian, A., \& Komala, E. (2019). Kemampuan Koneksi Matematik dan Motivasi Belajar Siswa dengan Menggunakan Model Problem-Based Learning (PBL) Berbantuan Geogebra di SMP. PRISMA, 8(1), 1-13. https://doi.org/10.35194/jp.v8i1.438

Shadiq, F. (2004). Pemecahan Masalah, Penalaran, dan Komunikasi.

Sugiyono. (2013). Metode Penelitian Pendidikan (Pendekatan Kuantitatif, Kualitatif, dan $R \& D) .46-59$.

Suwarman, R. F. (2017). Pengaruh Model Pembelajaran Auditory, Intellectually, Repetition (Air) terhadap Peningkatan Pemecahan Masalah Matematis Siswa. PRISMA, 6(2). https://doi.org/10.35194/jp.v6i2.58

Tati, T., Zulkardi, Z., \& Hartono, Y. (2013). Pengembangan Perangkat Pembelajaran Berbasis Kontekstual Pokok Bahasan Turunan Di Madrasah Aliyah Negeri 3 Palembang. Jurnal Pendidikan Matematika, 3(1), 75-89. https://doi.org/10.22342/jpm.3.1.323.

Trianto. (2010). Mendesain Model Pembelajaran Inovatif Progresif Konsep, Landasan dan Implementasinya pada Kurikulum Tingkat Satuan Pendidikan. (2007), 2008-2009. 